\title{
Autonomous water-cleaning machine using so- lar energy in shrimp ponds
}

\author{
Nghiên cứu, phát triển thiết bị tụ hành làm sạch nước trong vuông tôm sủ dụng \\ năng lượng mặt trời
}

Research article

Dang, Thien Ngon*

Department of Machine Manufacturing Technology, Hochiminh University of Technical Education, 01 Vo Van Ngan street - Thu Duc District, Ho Chi Minh City, Vietnam

\begin{abstract}
Limited water exchange shrimp culture technology is commonly used today in many shrimp farms in Vietnam to reduce water usage, input of diseases and discharge of nutrient-rich effluents into environment as well as to increase the production per unit area. However, a remaining problem in this technology is that the water quality in shrimp ponds will be reduced due to limitation of water exchange for a long period. The accumulation of inorganic components such as waste feed, bacterial deposits or other biological debris at the pond bottom will lead to low dissolved oxygen, high ammonia-nitrogen level, high fecal coliform bacteria and high turbidity which cause a severe degradation of water quality and detriment to shrimp growth and survival. To solve this remaining problem, an autonomous water-cleaning machine for shrimp ponds was designed to control the waste accumulation in the pond. This is an effective solution to replace manual cleaning methods for water quality management in shrimp farming in the coastal area of the Mekong delta of Vietnam. Especially, this technique can be used for biosecure shrimp production systems according to GMP standards to meet the objectives for sustainable development of shrimp aquaculture in Vietnam.
\end{abstract}

Kỹ thuật nuôi tôm không thay nước đang được sủ dụng rộng rãi ở các trại nuôi tôm Việt Nam vì giúp giảm luợng nuớc sủ dụng, hạn chế thải nuớc vào môi truờng và giúp tăng diện tích nuôi trồng tôm. Tuy nhiên, bản thân kỹ thuật này cũng tạo nên một sản phẩm chất thải là phân tôm, thức ăn và chế phẩm sinh học xử lý nước dư thùa. Chất thải này dần dần tích tu dưới đáy ao tạo thành lớp bùn độc, rất thiếu ôxy và chứa nhiều chất gây hại nhu ammonia, nitrite, hydrogen sulfide. Để tránh làm giảm diện tích ao nuôi do chất thải tích tụ làm tôm lảng tránh và tăng mật độ tôm nuôi trồng, thiết bi tư hành thu gom chất thải làm sach nước trong vuông nuôi tôm đã đuợc nghiên cứu, thiết kế và chế tạo thành công. Thiết bị đã thay thế các hoạt động làm sạch chất thải thủ công của con người, không sủ dụng các nguồn năng lượng gây ô nhiễm, giảm nhu cầu về điện góp phẩn phát triển sản xuất tôm sạch đạt chuẩn GMP và phát triển bền vũng ở các tỉnh ven biển miền Tây Việt Nam.

Keywords: autonomous machine, shrimp farming, shrimp pond, solar energy

\section{Introduction}

The rapid growth of shrimp culture for two recent decades has increased the area of shrimp aquaculture in the world, and has brought a lot of changes in aquaculture technology. The advanced technologies have appeared in shrimp breeding, feed formulation, and water treatment. Of these, water treatment without water exchange, but with biological products is one of the most advanced techniques (Luong, 2007). Because of not exchanging water, most of feed, shrimp waste, and waste bio-products treating water were accumulated at the pond bottom, and formed the polluted mud layer lacking oxygen and containing harmful material such as ammonia, nitrite, hydrogen sulphide (Ngoc Lan Environmental Company, 2010). So, shrimps often avoid this place, and concentrate in cleaner places. This reduces feeding areas but increases shrimps' eating competition. If the whole pond bottom is contaminated, then shrimps have to live in a polluted environment, and get stress shown through their eating and growth reduction. So they easily get infection by bacteria and die. To treat the water and cleanse the contaminated mud layer, 
shrimp farms have used the following manual technique: to have workers taking out this mud. However, in rice harvest time, shrimp farmers do not easily have enough workers for this work.

In order to contribute to treatment of water and contaminated mud in shrimp ponds, the design and use of treating water and polluted mud machine using solar energy may solve the current problem of pollution in shrimp ponds. It is also the solution to solve problem of lacking workforce in the harvest time. Solar energy is a source of available and abundant energy in shrimp ponds along the coastal areas.

\section{Operation Principle}

Shrimp ponds generally have dimension of: $100 \mathrm{~m} \times 100$ $\mathrm{m}$ or $100 \mathrm{~m} \times 70 \mathrm{~m}$ in which oxygen is supplied by propellers installed at the sides (Viet, 2007). With this arrangement, when operating, the oxygen propellers push waste material to the middle of the ponds (Fig. 1).

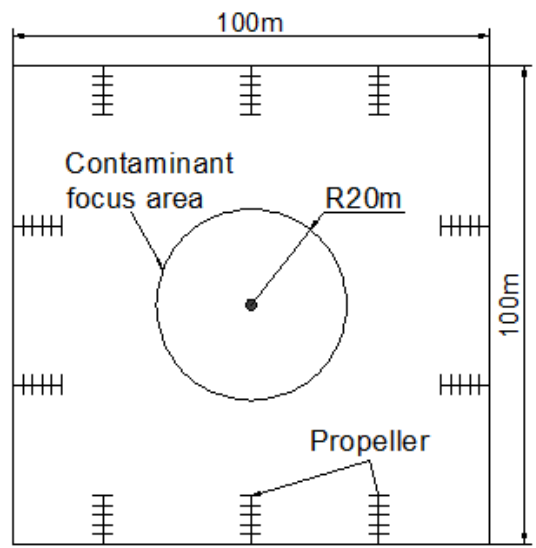

Figure 1. Shrimp pond and system of oxygen supply

In order to cleanse the water and solve the deposit of waste matter that forms the polluted mud at the pond bottom, the filter of water must be carried out every day. Waste matter is particles of bio-products [S], of feed and sized rubbish, so we can use mechanical filtering technique to cleanse the water. Thus, the water-filtering device must meet the following requirements:

- Sucking up the water from the pond with different depth from $0.1 \mathrm{~m} \div 0.8 \mathrm{~m}$ measured from water level (depth of shrimp ponds is about $1.2 \mathrm{~m}$ (Viet, 2007))

- Filtering the water by filter net to keep waste matter and give the filtered water back to the pond

- This machine can self-operate with the moving in spiral trajectory outside to suck dirty water accumulated in the middle of the pond and vice versa

- The machine works according to the programmed cycles and is easy to adjust

- Simple design allows taking out waste matter and cleanse the filter net easily and quickly

- Energy saving, simple and convenient supply of energy.

\section{Design of autonomous water- cleaning machine}

From the requirements and operation principle mentioned, the autonomous water-cleaning machine is designed as follows:

\subsection{Unit of sucking tube}

The unit of sucking tube works as a guide tube and pressure one to suck water from the pond up to the filtering tank. This tube can move up and down to change the depth of sucking. To do this work, the structure of sucking tube is designed as in Figure 2. The unit of sucking tube consists of: a fixed tube attached to the filtering tank with 4 outlets above; the translation tube can move up and down by gear and rack, this tube has holes along its body to take in water; a motor is installed above the fixed tube; this motor connects with the propeller to suck water. The gear and rack are controlled by a motor and the moving distance is controlled by limit switch.

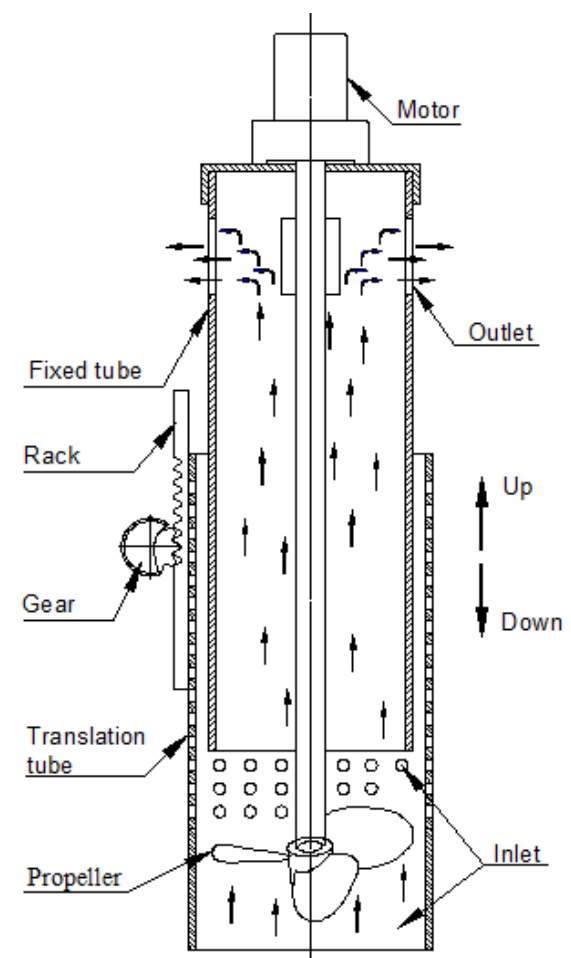

Figure 2. Structure of sucking tube unit

\subsection{Filtering Tank}

The filtering technique applied here is a mechanical method (Tran and Ngo, 2002) using filter net to clean water. The filtering tank is shown in Figure 3. This tank is attached to the unit of sucking tube. It has two bottoms: the upper bottom is a perforated sheet (5) for filtered water to go out; the lower bottom has water outlets (4). When sucked up, water goes through the outlets of the sucking tube and flows into the tank (1), then through the filter net (3), through the holes on the sheet (5), through the outlets (4) to return to the shrimp pond. 


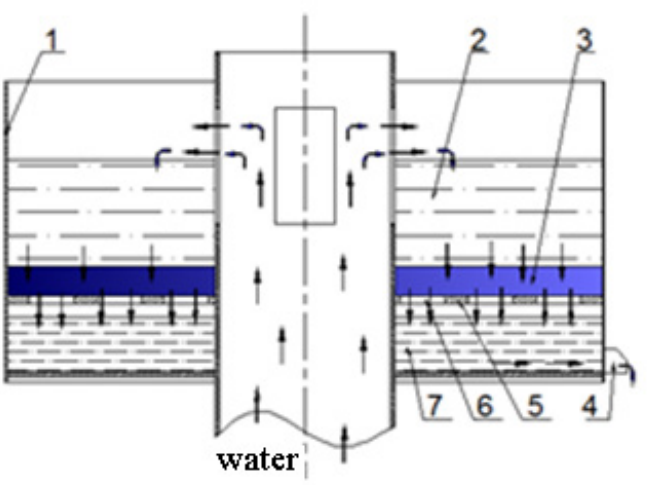
1.Tank
2. Water sucked up
3. Filter net
4. Water outlet

5. Perforated sheet

6. Holes for water out

7. Filtered water

Figure 3. Filtering Tank

\subsection{Mechanism of motion drive}

In order to move in spiral trajectory to and fro, the machine is installed two motors; one on the left (1) and one on the right (2). Each motor is connected with the propeller (3) and under the control of mutual lock (Figure 4).

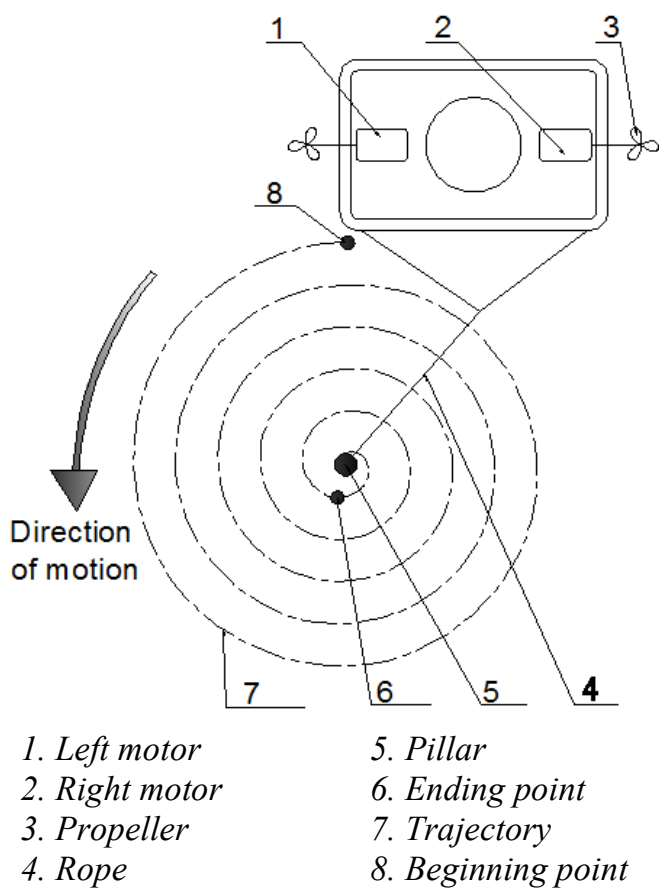

Figure 4. Mechanism of motion drive and trajectory

When the right motor (2) works, the propeller helps the machine move anticlockwise, suck contaminated water, and then filter it. To enable the machine to move in spiral trajectory, the machine is connected with a fixed pillar (5) in the middle of the pond by a rope (4). This rope keeps the machine from being blown away by wind. When the machine works, the rope (4) will wind around the pillar (5), forming the spiral trajectory movement (7). When coming up to the pillar, the right motor (2) is controlled to stop. Then the left motor (1) is activated to make the machine move away in the contrary direction.

\subsection{Energy Unit}

The system uses electric source taken from solar energy to supply the electricity to the motors and control devices. The energy unit consists of:

- Two solar cell sheets $(\mathrm{P}=80 \mathrm{~W}, \mathrm{I}=4.54 \mathrm{~A}, \mathrm{U}=17.64 \mathrm{~V})$

- Two batteries $6 \mathrm{Ah}, 12 \mathrm{~V}$

- Control circuit supplying electricity to two batteries (Figure 5)

According to calculation, the batteries with full energy can help the self-operating machine continuously work for over one hour.

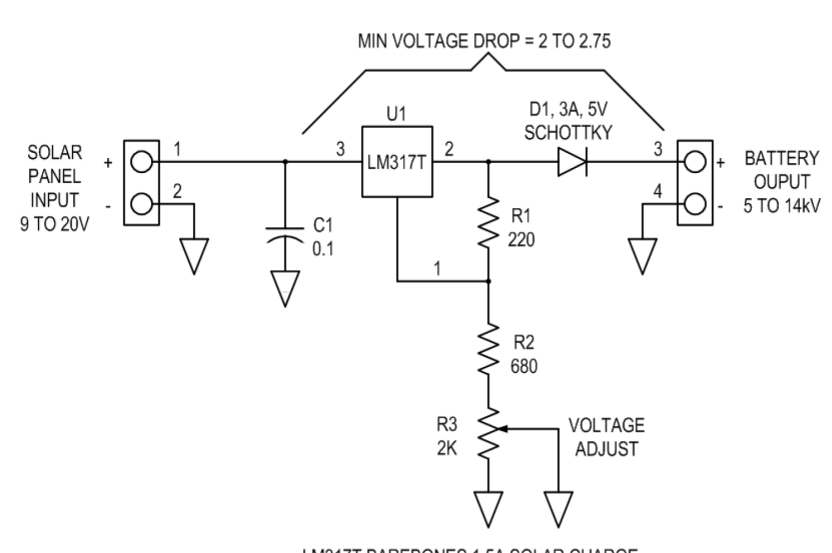

Figure 5. Solar Charge Control Schematic (Electroschematics, 2012)

\subsection{Controller design}

The controller is designed to perform these jobs:

- To control the machine to work automatically and cyclically

- The controller works in real-time

- Not working during the time of feeding shrimps and two hours later

- During the time of not feeding shrimps, the machine filters water for 15 minutes per hour

- From 7 PM to 7 AM, the machine stops working

- To control the charge circuit for batteries; control the motor of sucking water, the motor of raising and lowering the translation tube for change of sucking depth; the motors of moving the machine.

With these requirements, the designed controller uses PLC Siemens S7-200 (CPU 224). The control program for it is not so complicated, and successfully designed and programmed.

\subsection{Development and test of machine}

On the base of the design mentioned above, the autonomous water-cleaning machine using solar energy in shrimp ponds has been created and successfully tested. It meets all the given technical requirements. The compo- 
nents of the machine are shown in detail in Figure 6 while Figure 7 shows the completed machine.

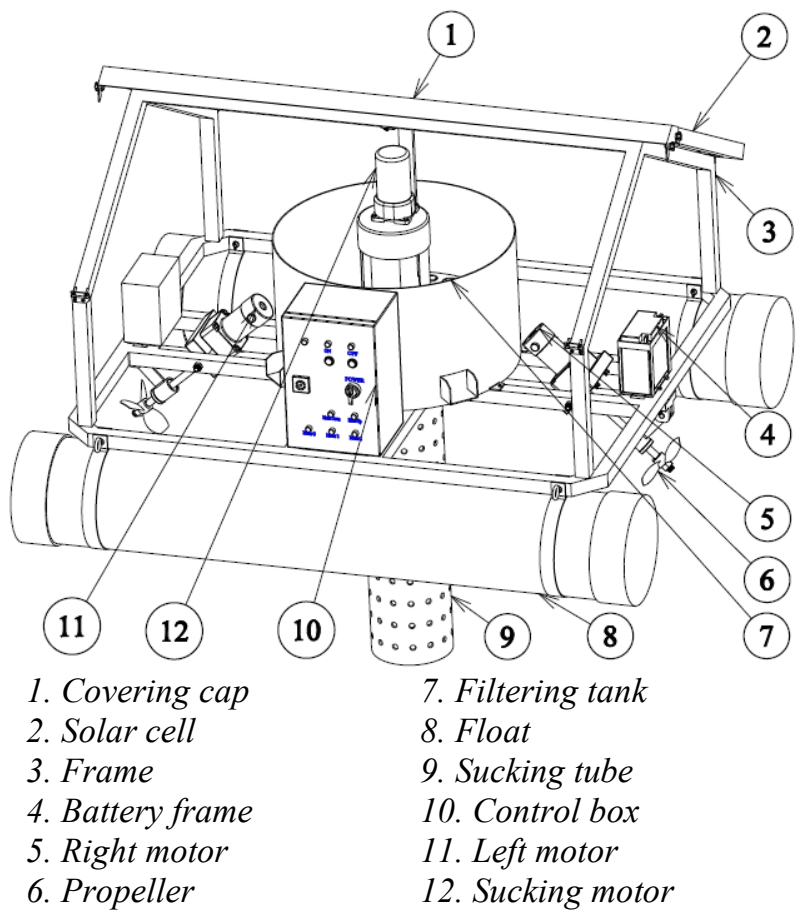

Figure 6. Components of autonomous water cleaning machine using solar energy

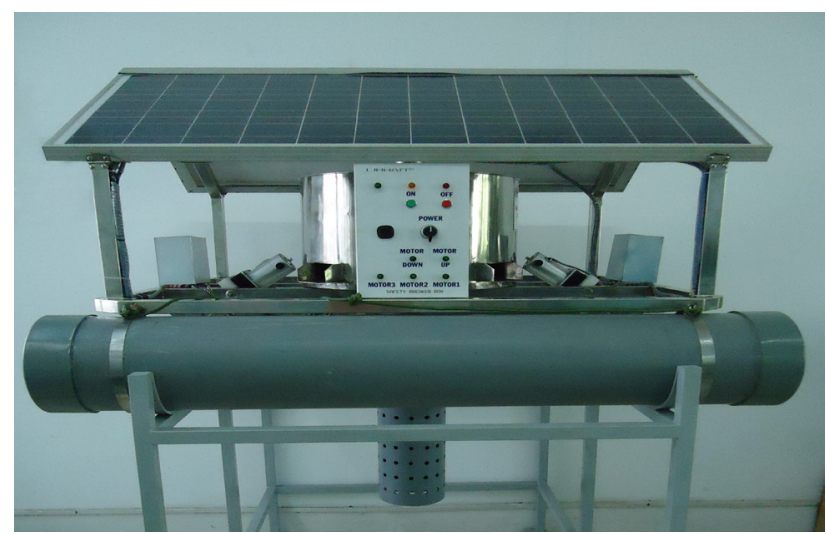

Figure 7. Autonomous water cleaning machine using solar energy

\section{Evaluation}

The machine was put into test on its structure, operation capacity, and other criteria in ponds in Thu Duc District, Hochiminh City. The results showed that the machine met the design requirements, sucking power and autonomous operation in spiral trajectory. Figure 8 shows the machine test in practice.

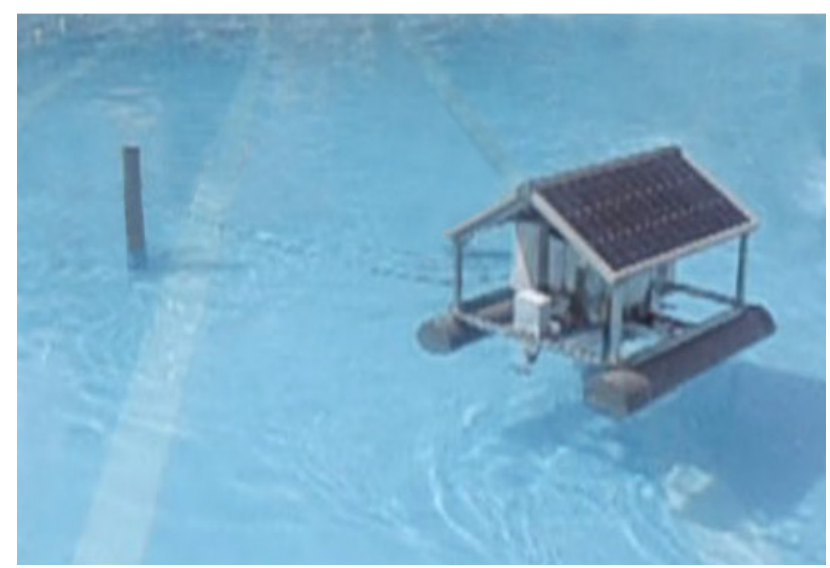

Figure 8. Machine Test

\section{Conclusion}

This article presents the design, development of autonomous water-cleaning machine using solar energy in shrimp ponds. The machine was developed and tested. Results showed that it met the technical requirements. It can automatically operate in movement of spiral trajectory, according to the set cycles, and with remote control. By using the mechanical filter, the machine can help get rid of waste matter in shrimp culture. It can replace the manual way of cleaning water in shrimp ponds, use no source of energy causing pollution, help reduce the electricity demands, contribute to production of good shrimps under GMP standards, and to sustainable development in the coastal provinces in western part of Vietnam.

The next development is to study on reduction of machine mass by using composite material for the frame and tank. In addition, on the base of autonomous water-cleaning machine using solar energy in shrimp ponds, a research in development of automatic fish feeding machine will be done. This machine will serve the fish aquaculture in southern provinces and every part all over the country.

\section{References}

[1] Luong, D.P. 2007. Biological wastewater treatment technology. Viet Nam Education Publishing House (in Vietnamese).

[2] Tran, V.N., Ngo, T.N. 2002. Wastewater treatment technology - Textbook. Publishing house for Science $\&$ Technology (in Vietnamese).

[3] Viet, C. 2007. Culture technology of tiger shrimp, giant shrimp, trionychid turtle. Universal Publisher of Ho Chi Minh City.

[4] Electroschematics, 2012. Solar battery charger circuit

[5] Ngoc Lan Environmental Company, 2010. Shrimp farm wastewater treatment. 